\title{
Biochar addition alleviate the negative effects of drought and salinity stress on soybean productivity and water use efficiency
}

Yaojun Zhang ${ }^{1 *}$ (D) Jiaqi Ding ${ }^{1}$, Hong Wang ${ }^{2}$, Lei Su ${ }^{1}$ and Cancan Zhao ${ }^{1 *}$

\begin{abstract}
Background: Environmental stress is a crucial factor restricting plant growth as well as crop productivity, thus influencing the agricultural sustainability. Biochar addition is proposed as an effective management to improve crop performance. However, there were few studies focused on the effect of biochar addition on crop growth and productivity under interactive effect of abiotic stress (e.g., drought and salinity). This study was conducted with a pot experiment to investigate the interaction effects of drought and salinity stress on soybean yield, leaf gaseous exchange and water use efficiency (WUE) under biochar addition.

Results: Drought and salinity stress significantly depressed soybean phenology (e.g. flowering time) and all the leaf gas exchange parameters, but had inconsistent effects on soybean root growth and WUE at leaf and yield levels. Salinity stress significantly decreased photosynthetic rate, stomatal conductance, intercellular $\mathrm{CO}_{2}$ concentration and transpiration rate by 20.7, 26.3, 10.5 and 27.2\%, respectively. Lower biomass production and grain yield were probably due to the restrained photosynthesis under drought and salinity stress. Biochar addition significantly enhanced soybean grain yield by 3.1-14.8\%. Drought stress and biochar addition significantly increased WUE-yield by 27.5 and $15.6 \%$, respectively, while salinity stress significantly decreased WUE-yield by $24.2 \%$. Drought and salinity stress showed some negative interactions on soybean productivity and leaf gaseous exchange. But biochar addition alleviate the negative effects on soybean productivity and water use efficiency under drought and salinity stress.
\end{abstract}

Conclusions: The results of the present study indicated that drought and salinity stress could significantly depress soybean growth and productivity. There exist interactive effects of drought and salinity stress on soybean productivity and water use efficiency, while we could employ biochar to alleviate the negative effects. We should consider the interactive effects of different abiotic restriction factors on crop growth thus for sustainable agriculture in the future.

Keywords: Biochar, Crop productivity, Drought stress, Leaf gaseous exchange, Salinity stress, Water use efficiency

\footnotetext{
* Correspondence: njauyjzhang@163.com; cczhao2008@163.com

${ }^{1}$ School of Life Sciences, Henan University, Kaifeng 475004, Henan, China

Full list of author information is available at the end of the article
}

(c) The Author(s). 2020 Open Access This article is licensed under a Creative Commons Attribution 4.0 International License, which permits use, sharing, adaptation, distribution and reproduction in any medium or format, as long as you give appropriate credit to the original author(s) and the source, provide a link to the Creative Commons licence, and indicate if changes were made. The images or other third party material in this article are included in the article's Creative Commons licence, unless indicated otherwise in a credit line to the material. If material is not included in the article's Creative Commons licence and your intended use is not permitted by statutory regulation or exceeds the permitted use, you will need to obtain permission directly from the copyright holder. To view a copy of this licence, visit http://creativecommons.org/licenses/by/4.0/ The Creative Commons Public Domain Dedication waiver (http://creativecommons.org/publicdomain/zero/1.0/) applies to the data made available in this article, unless otherwise stated in a credit line to the data. 


\section{Background}

Drought induced by water scarcity is a major limitation to the sustainability of global crop production $[1,2]$. High frequency and severity of droughts have been predicted throughout the world in the future, including most parts of China, due to global warming and expected frequency of extreme climatic events [3-5]. Crop yield could be restrained by drought stress has been well documented in previous studies [6-10]. For instance, drought stress could significantly decrease soybean grain yield by $24-50 \%$ but gain higher water use efficiency (WUE) [11]. Meanwhile, WUE is an important trait for indicating plant resistance under drought stress [12].

Drought stress could alter physiological characteristics of plant leaves, such as lowering leaf photosynthetic and transpiration rate and stomatal conductance, thus restraining crop productivity [13-15]. In addition, drought stress could also affect plant phenology (e.g., advance or delay flowering time) and then influence crop productivity [16]. It has been reported that water shortage at flowering stage negatively affected chickpea (Cicer arietinum Linn.) yield [17], but soybean (Glycine max L.) flowering time was observed no response under drought stress [11]. Besides, root is always playing an important role in regulating crop productivity under drought stress, especially for the legume crop with nodules can fix $\mathrm{N}_{2}$ from atmosphere used as $\mathrm{N}$ nutrition [2, $18,19]$. For instance, plant always has deeper roots being able to assimilate more water and nutrition from deeper soil under drought stress [20].

Salinity is another one vital limiting factor for sustainable agriculture with depressing crop growth and production worldwide [21-23]. Globally, more than 70 countries have been characterized as existing large areas of salinity-affected lands and over $6 \%$ of the world's total land is affected by salinity stress [24, 25]. Salinity stress could not only reduce crop yield through affecting leaf physiological growth [26], but also could reduce the ability of plant roots to take up water and nutrition (e.g., N) from soil [27, 28]. While other studies showed that salinity could increase transgenic barley growth and yield in both glasshouse and field conditions, but the mechanisms were unclear [29].

Biochar, a stable C-rich byproduct obtained from biomass, application to low fertility soils is a promising approach to improve soil quality and thus crop productivity [30-32]. Generally, biochar application could increase crop productivity mainly occurred in acidic and neutral $\mathrm{pH}$ soils $[31,33]$, but there were less studies on alkaline soil under drought stress.

Soybean, as one of the world's most widely grown legume crops with a total production of more than 346 million tons in 2016 (FAO stat, http://www.fao.org/faostat/
en/\#data/QC), provides large amounts of protein and edible oil for human consumption [34]. This important legume crop, however, is affected by several abiotic stressors, such as drought and salinity, which could significantly restrict soybean growth and productivity [8, 11, 34, 35]. Previous studies have gained widely insight into the soybean productivity affected by drought and salinity, however, the physiological basis underlying the yield reduction is still not clear. In addition, whether biochar addition could be used as an effective management to infertile soil under the combination stress of drought and salinity is scarce. Thus, a better understanding of biochar addition on physiological basis and root traits for soybean growth under drought and salinity stress will be beneficial for sustainable agriculture.

Here, this study was carried out to examine biochar addition on soybean leaf physiological parameters, crop productivity and WUE at leaf and yield levels under the combination of drought and salinity stress. The aim of this study was to evaluate the single and interactive effect of these treatments on soybean productivity. This study have tested three main hypotheses: 1) drought stress could decrease soybean leaf physiological parameters and thus crop productivity, 2) salinity stress could aggravate the negative effects of drought stress, and 3) biochar addition could alleviate the constrain effects of drought and salinity stress.

\section{Results}

Soybean phenology and leaf gas exchange parameters Soybean phenology (e.g. flowering time) and all leaf gas exchange parameters were significantly affected by drought and salinity stress, while no significant effect was observed as consequence of biochar addition, except for photosynthetic rate and stomatal conductance (Table 1). Drought stress at low and high intensity significantly decreased leaf photosynthetic rate by 26.3 and $37.9 \%$, stomatal conductance by 38.9 and $55.0 \%$, intercellular $\mathrm{CO}_{2}$ concentration by 15.8 and $17.1 \%$ and transpiration rate by 49.6 and $71.2 \%$. On the contrary, drought stress significantly increased $\mathrm{WUE}_{\text {-leaf }}$ by 45.4 and $102.4 \%$ at D-L and D-H treatments, respectively. Soybean flowering time was delayed by almost 1 day under salinity stress. In addition, salinity stress significantly decreased photosynthetic rate, stomatal conductance, intercellular $\mathrm{CO}_{2}$ concentration and transpiration rate $(-20.7,-26.3 \%,-10.5 \%$ and $27.2 \%$, respectively) relative to the non-salinity treatment.

The present study showed few interactive effects of treatments on leaf gas exchange parameters and no effect on soybean flowering time (Table 1, Fig. 1). Photosynthetic rate and stomatal conductance were significantly influenced by interactions both drought $x$ 
Table 1 Flowering time, $P_{- \text {max }}$ Cond, $C i$, $\operatorname{Tr}$ and WUE-leaf of soybean at the flowering stage. Different letters within each treatment indicate significant differences for Fisher LSD test

\begin{tabular}{|c|c|c|c|c|c|c|}
\hline & $\begin{array}{l}\text { Flowering time } \\
\text { days }\end{array}$ & $\begin{array}{l}P_{-\max } \\
\mu \mathrm{mol} \mathrm{CO}_{2} \mathrm{~m}^{-2} \mathrm{~s}^{-1}\end{array}$ & $\begin{array}{l}\text { Cond } \\
\text { mol } \mathrm{H}_{2} \mathrm{O} \mathrm{m}^{-2} \mathrm{~s}^{-1}\end{array}$ & $\begin{array}{l}\mathrm{Ci} \\
\mu \mathrm{mol} \mathrm{CO} \\
\mathrm{mol}^{-1}\end{array}$ & $\begin{array}{l}\mathrm{Tr} \\
\mathrm{mmol} \mathrm{H} \mathrm{O} \mathrm{m}^{-2} \mathrm{~s}^{-1}\end{array}$ & $\begin{array}{l}\text { WUE }_{\text {-leaf }} \\
\mu \mathrm{mol} \mathrm{mmol}^{-1}\end{array}$ \\
\hline \multicolumn{7}{|c|}{ Drought stress (D) } \\
\hline$D-C$ & $41.75 \pm 0.32 c$ & $10.20 \pm 0.68 \mathrm{a}$ & $0.49 \pm 0.03 \mathrm{a}$ & $325.29 \pm 7.27 \mathrm{a}$ & $11.69 \pm 0.85 a$ & $0.95 \pm 0.09 c$ \\
\hline D-L & $42.92 \pm 0.41 b$ & $7.51 \pm 0.47 b$ & $0.30 \pm 0.01 \mathrm{~b}$ & $273.83 \pm 4.90 \mathrm{~b}$ & $5.89 \pm 0.55 b$ & $1.38 \pm 0.08 b$ \\
\hline $\mathrm{D}-\mathrm{H}$ & $44.54 \pm 0.26 \mathrm{a}$ & $6.34 \pm 0.21 b$ & $0.22 \pm 0.01 c$ & $269.69 \pm 6.16 b$ & $3.37 \pm 0.16 c$ & $1.93 \pm 0.06 \mathrm{a}$ \\
\hline \multicolumn{7}{|c|}{ Salinity stress (S) } \\
\hline Control & $42.58 \pm 0.33 b$ & $8.94 \pm 0.56 a$ & $0.38 \pm 0.03 \mathrm{a}$ & $305.58 \pm 7.17 \mathrm{a}$ & $8.08 \pm 0.83 a$ & $1.36 \pm 0.09 a$ \\
\hline Salinity & $43.56 \pm 0.32 \mathrm{a}$ & $7.09 \pm 0.33 b$ & $0.28 \pm 0.02 b$ & $273.62 \pm 4.57 b$ & $5.88 \pm 0.63 b$ & $1.48 \pm 0.09 a$ \\
\hline \multicolumn{7}{|l|}{ Biochar (B) } \\
\hline BO & $43.17 \pm 0.40 \mathrm{a}$ & $7.02 \pm 0.45 b$ & $0.31 \pm 0.03 b$ & $289.18 \pm 7.70 \mathrm{a}$ & $6.13 \pm 0.76 a$ & $1.38 \pm 0.11 \mathrm{a}$ \\
\hline B1 & $42.96 \pm 0.41 \mathrm{a}$ & $8.47 \pm 0.75 a$ & $0.35 \pm 0.04 \mathrm{a}$ & $285.04 \pm 7.67 \mathrm{a}$ & $7.42 \pm 1.00 \mathrm{a}$ & $1.39 \pm 0.11 \mathrm{a}$ \\
\hline B2 & $43.08 \pm 0.42 \mathrm{a}$ & $8.55 \pm 0.48 \mathrm{a}$ & $0.34 \pm 0.03 \mathrm{ab}$ & $294.58 \pm 7.85 a$ & $7.40 \pm 1.01 \mathrm{a}$ & $1.50 \pm 0.12 \mathrm{a}$ \\
\hline \multicolumn{7}{|l|}{ ANOVA } \\
\hline $\mathrm{D}$ & $<0.001$ & $<0.001$ & $<0.001$ & $<0.001$ & $<0.001$ & $<0.001$ \\
\hline S & $<0.01$ & $<0.001$ & $<0.001$ & $<0.001$ & $<0.01$ & 0.055 \\
\hline B & 0.896 & $<0.01$ & $<0.05$ & 0.369 & 0.156 & 0.274 \\
\hline$D \times S$ & 0.057 & $<0.01$ & $<0.001$ & 0.079 & 0.141 & $<0.001$ \\
\hline$D \times B$ & 0.550 & 0.562 & 0.174 & 0.146 & 0.164 & 0.070 \\
\hline$S \times B$ & 0.469 & $<0.05$ & 0.094 & $<0.05$ & 0.401 & $<0.001$ \\
\hline$D \times S \times B$ & 0.328 & $<0.05$ & $<0.05$ & 0.156 & 0.717 & 0.339 \\
\hline
\end{tabular}

Note: $P_{- \text {max }}$ leaf maximum photosynthetic rate; Cond, stomatal conductance; $\mathrm{Ci}$, intercellular $\mathrm{CO}_{2}$ concentration; $\mathrm{Tr}$, transpiration rate; WUE $\mathrm{E}_{-\mathrm{leaf}}$ leaf water use efficiency

salinity and drought $\times$ salinity $\times$ biochar. Intercellular $\mathrm{CO}_{2}$ concentration was significantly affected only by salinity $\times$ biochar addition interaction. $\mathrm{WUE}_{\text {-leaf }}$ showed significant changes considering drought $\times$ salinity and salinity $\times$ biochar addition interaction.

\section{Biomass production}

Drought and salinity stress significantly affected soybean biomass productivity and root growth (Table 2). With drought stress increasing, shoot biomass $(-28.9 \%$ and $48.3 \%$ at $\mathrm{D}-\mathrm{L}$ and $\mathrm{D}-\mathrm{H}$, respectively), root biomass ($4.7 \%$ and $-34.3 \%$ at $\mathrm{D}-\mathrm{L}$ and $\mathrm{D}-\mathrm{H}$, respectively) and total biomass $(-25.5 \%$ and $-46.3 \%$ at $\mathrm{D}-\mathrm{L}$ and $\mathrm{D}-\mathrm{H}$, respectively) were depressed significantly compared with the control. On the contrary, drought stress significantly increased root length (21.7 and $10.6 \%$ at D-L and D-H, respectively) compared with the control and the longest root length occurred in D-L treatment.

Salinity stress significantly decreased root biomass ($24.5 \%)$ and total biomass $(-13.2 \%)$ relative to control treatment. In accordance with root biomass, salinity stress significantly decreased root length by $21.7 \%$ compared with control.

Biochar addition showed significantly effects on shoot biomass, root biomass and total biomass, but had no effect on the ratio of shoot/root and root length (Table 2). With biochar addition rate increasing, higher shoot biomass (14.3 and $43.6 \%$ at B1 and B2, respectively), root biomass (15.8 and $31.5 \%$ at B1 and B2, respectively) and total biomass (14.6 and $41.6 \%$ at B1 and B2, respectively) than control were observed.

Generally, biomass production was partially affected by the interactive effects of drought stress, salinity stress and biochar addition (Table 2). Specifically, drought $\times$ salinity stress interaction significantly affected root length, root biomass and the total biomass production (Fig. 2). It is worth mentioning that root length showed no difference among drought stress when salinity was added, but without salinity addition root length was enhanced by $35.5 \%$ under D-L and $28.1 \%$ under D-H compared to D-C treatment (Fig. 2j). In addition, the drought stress $\times$ biochar addition interaction significantly affected shoot biomass, total biomass, and root length but not root biomass. With biochar addition increasing, drought stress depressed shoot biomass (averaged from $-19.0 \%$ to $-53.8 \%$ ) and total biomass (averaged from $-14.8 \%$ to $-51.7 \%$ ) stronger compared with control. Particularly, drought stress significantly increased root length (55.2 and 50.6\% at low and high drought stress, respectively) only in B1 treatment. 


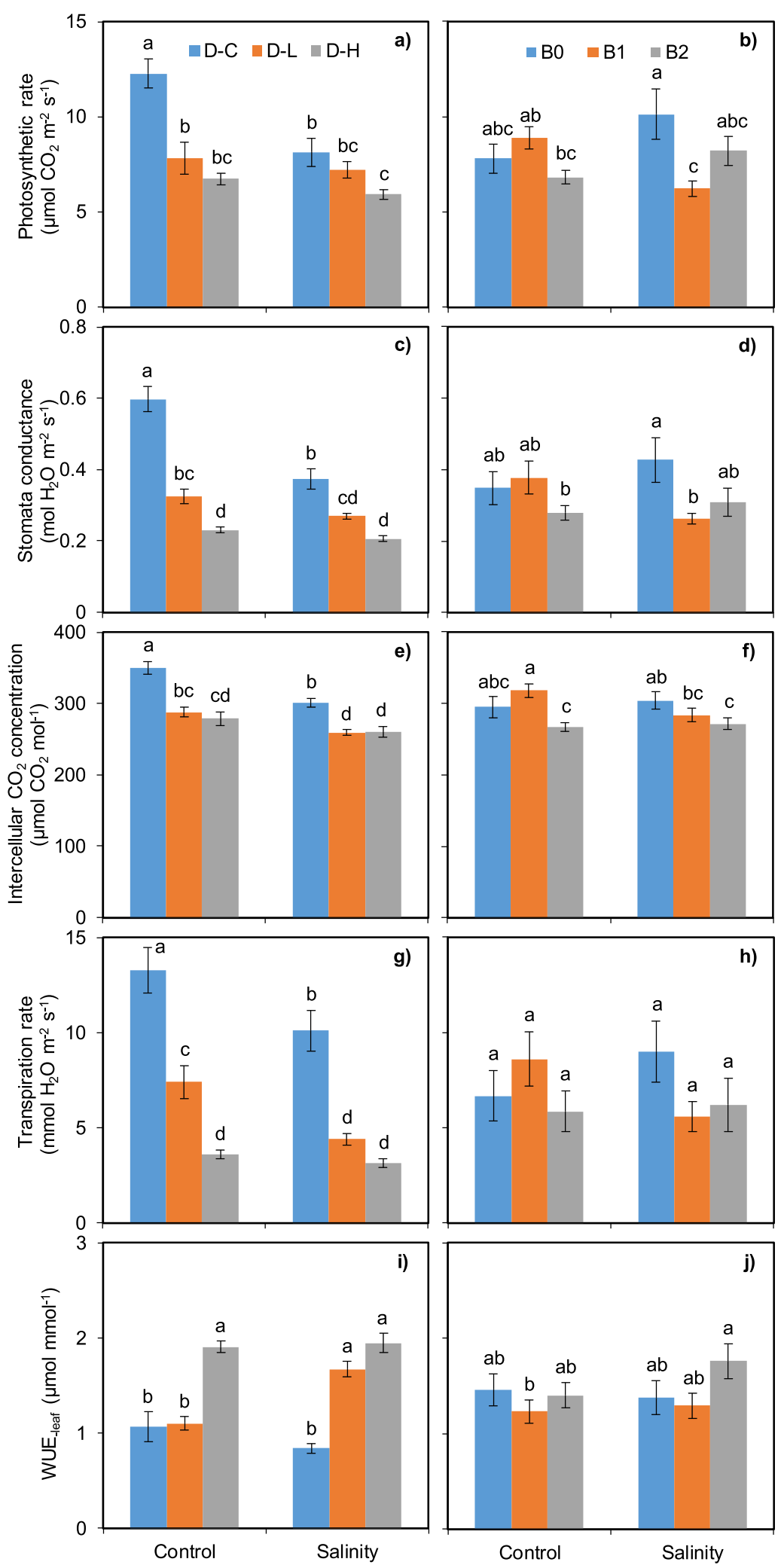

Fig. 1 (See legend on next page.) 
(See figure on previous page.)

Fig. 1 Leaf photosynthetic rate $(\mathbf{a}, \mathbf{b})$, stomatal conductance $(\mathbf{c}, \mathbf{d})$, intercellular $\mathrm{CO}_{2}$ concentration $(\mathbf{e}, \mathbf{f})$, transpiration rate $(\mathbf{g}, \mathbf{h})$ and WUE as affected by the interactive effects of drought $\times$ salinity stress and biochar $\times$ salinity stress. D-C $=$ no drought stress; D-L = low drought stress; D$\mathrm{H}=$ high drought stress. The bars indicate the standard error of the means ( \pm SE). Different letters indicate significant differences according to the Fisher's LSD test

\section{Grain yield}

Soybean gained the highest grain yield $\left(10.46 \mathrm{~g} \mathrm{pot}^{-1}\right)$ at the D-C treatment with well irrigation. Drought stress significantly reduced the grain yield of soybean by 17.7 and $42.6 \%$ under low and high drought, respectively (Table 2). Similarly, salinity stress significantly lowered the grain yield by $21.1 \%$ compared with the treatment with no salinity addition. While, biochar addition significantly enhanced grain yield by $3.1-14.8 \%$ compared with the control.

Soybean grain yield was partially affected by the interactive effects of studied treatments (Table 2). As expected, drought $\times$ salinity stress interaction significantly affected grain yield with worse performance when salinity was added together with drought stress (Fig. 3). Besides, drought stress interaction with biochar addition also significantly affected soybean grain yield. No significant effect on soybean yield was observed considering the interaction of drought stress $\times$ salinity stress $\times$ biochar addition.
WUE-yield

Drought stress showed a positive effects on $\mathrm{WUE}_{\text {-yield }}$ while salinity stress showed a negative effects on

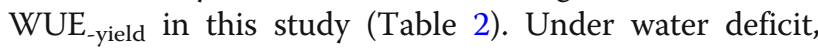
WUE $_{\text {-yield }}$ was increased by 27.5 and $25.5 \%$ under low and high drought stress, respectively. On the contrary, salinity stress significantly decreased $\mathrm{WUE}_{\text {-yield }}$ by $24.2 \%$ compared with the non-salinity addition soils. Biochar addition significantly enhanced WUE $_{\text {-yield }} 15.6 \%$ at high addition rate while showed no effect at low addition rate.

WUE $_{\text {-yield }}$ was significantly affected by the studied treatments interaction (Table 2, Fig. 3). Drought stress significantly increased $\mathrm{WUE}_{\text {-yield }}$ but salinity addition significantly decreased $\mathrm{WUE}_{\text {-yield }}$ under control treatment, however, biochar addition relieved the effects.

\section{Discussion}

Flowering stage is an important transition period for soybean vegetative and reproductive growth, and sensitive to

Table 2 Shoot biomass, root biomass, shoot/root, total biomass, root length, grain yield and WUE-yield of the soybean plant when harvesting. Different letters within each treatment indicate significant differences for Fisher LSD test

\begin{tabular}{|c|c|c|c|c|c|c|c|}
\hline & $\begin{array}{l}\text { Shoot biomass } \\
\mathrm{g} \mathrm{pot}^{-1}\end{array}$ & $\begin{array}{l}\text { Root biomass } \\
\mathrm{g} \mathrm{pot}^{-1}\end{array}$ & Shoot/root & $\begin{array}{l}\text { Total biomass } \\
\mathrm{g} \mathrm{pot}^{-1}\end{array}$ & $\begin{array}{l}\text { Root length } \\
\mathrm{cm}\end{array}$ & $\begin{array}{l}\text { Grain yield } \\
\mathrm{g} \mathrm{pot}^{-1}\end{array}$ & $\begin{array}{l}\text { WUE-yield } \\
\mathrm{gL}^{-1}\end{array}$ \\
\hline \multicolumn{8}{|c|}{ Drought stress (D) } \\
\hline$D-C$ & $19.80 \pm 1.21 \mathrm{a}$ & $3.24 \pm 0.25 a$ & $6.35 \pm 0.30 \mathrm{a}$ & $23.04 \pm 1.40 \mathrm{a}$ & $28.08 \pm 1.72 b$ & $10.46 \pm 0.64 \mathrm{a}$ & $0.51 \pm 0.03 b$ \\
\hline D-L & $14.08 \pm 0.85 b$ & $3.08 \pm 0.18 \mathrm{a}$ & $4.66 \pm 0.21 b$ & $17.17 \pm 0.98 b$ & $34.17 \pm 1.74 \mathrm{a}$ & $8.61 \pm 0.61 b$ & $0.65 \pm 0.05 \mathrm{a}$ \\
\hline $\mathrm{D}-\mathrm{H}$ & $10.23 \pm 0.74 c$ & $2.13 \pm 0.15 b$ & $4.96 \pm 0.29 b$ & $12.36 \pm 0.86 c$ & $31.04 \pm 2.37 \mathrm{ab}$ & $6.00 \pm 0.29 c$ & $0.64 \pm 0.03 a$ \\
\hline \multicolumn{8}{|c|}{ Salinity stress (S) } \\
\hline Control & $15.56 \pm 0.74 \mathrm{a}$ & $3.21 \pm 0.12 \mathrm{a}$ & $4.90 \pm 0.18 b$ & $18.76 \pm 0.82 \mathrm{a}$ & $34.88 \pm 1.83 a$ & $9.34 \pm 0.46 \mathrm{a}$ & $0.69 \pm 0.03 a$ \\
\hline Salinity & $13.86 \pm 1.22 \mathrm{a}$ & $2.42 \pm 0.21 b$ & $5.75 \pm 0.29 a$ & $16.28 \pm 1.39 b$ & $27.31 \pm 1.12 b$ & $7.37 \pm 0.55 b$ & $0.52 \pm 0.03 b$ \\
\hline \multicolumn{8}{|l|}{ Biochar (B) } \\
\hline BO & $12.33 \pm 0.82 b$ & $2.43 \pm 0.17 b$ & $5.20 \pm 0.27 \mathrm{a}$ & $14.76 \pm 0.96 b$ & $31.80 \pm 2.01 \mathrm{a}$ & $7.89 \pm 0.48 b$ & $0.57 \pm 0.04 b$ \\
\hline B1 & $14.09 \pm 1.03 b$ & $2.82 \pm 0.19 a b$ & $5.09 \pm 0.29 a$ & $16.91 \pm 1.16 b$ & $33.17 \pm 2.29 \mathrm{a}$ & $8.13 \pm 0.65 a b$ & $0.59 \pm 0.04 b$ \\
\hline B2 & $17.70 \pm 1.53 \mathrm{a}$ & $3.20 \pm 0.28 a$ & $5.68 \pm 0.35 \mathrm{a}$ & $20.90 \pm 1.74 \mathrm{a}$ & $28.31 \pm 1.60 \mathrm{a}$ & $9.05 \pm 0.78 \mathrm{a}$ & $0.66 \pm 0.03 a$ \\
\hline \multicolumn{8}{|l|}{ ANOVA } \\
\hline $\mathrm{D}$ & $<0.001$ & $<0.001$ & $<0.01$ & $<0.001$ & $<0.05$ & $<0.001$ & $<0.001$ \\
\hline S & 0.051 & $<0.001$ & $<0.01$ & $<0.05$ & $<0.001$ & $<0.001$ & $<0.001$ \\
\hline B & $<0.001$ & $<0.01$ & 0.438 & $<0.001$ & 0.090 & $<0.05$ & $<0.05$ \\
\hline$D \times S$ & 0.059 & $<0.05$ & 0.820 & $<0.05$ & $<0.05$ & $<0.001$ & $<0.001$ \\
\hline$D \times B$ & $<0.05$ & 0.401 & 0.534 & $<0.05$ & $<0.05$ & $<0.001$ & $<0.001$ \\
\hline$S \times B$ & $<0.05$ & $<0.05$ & 0.853 & $<0.05$ & 0.714 & $<0.01$ & $<0.01$ \\
\hline$D \times S \times B$ & 0.682 & 0.499 & 0.716 & 0.633 & $<0.05$ & 0.160 & 0.160 \\
\hline
\end{tabular}




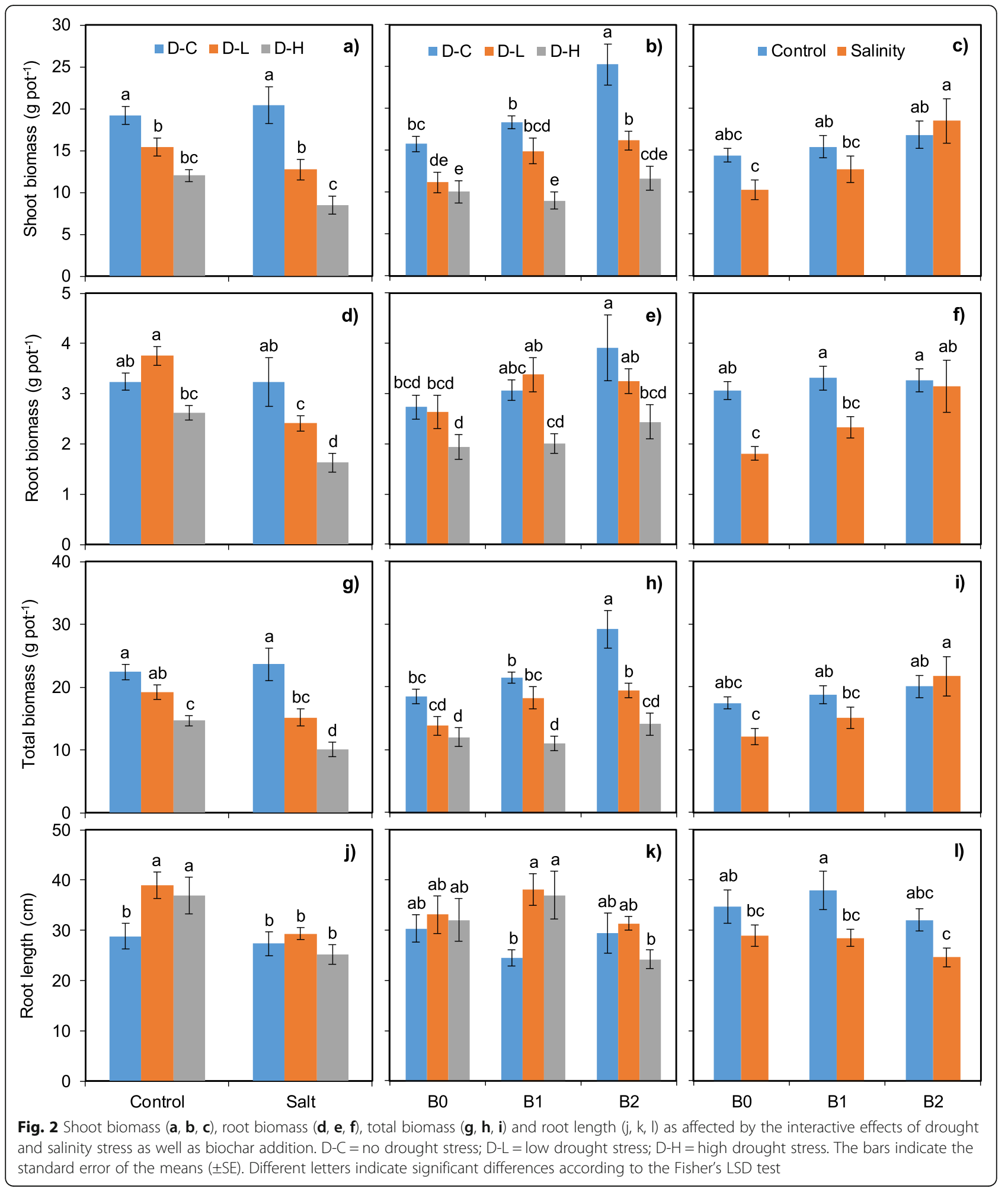

drought and salinity stress [36]. Both drought and salinity stress delayed soybean flowering time in this study, which should be an underlying mechanism for soybean adapting to the rigorous habitat. Previous studies have shown that drought and salinity stress could delay crop flowering time thereby making a negative effect on crop productivity [11, $21,37,38]$. The present study is in consistent with the above reported literature findings, which might be attributed to the greater water consumption with later flowering time [11]. 


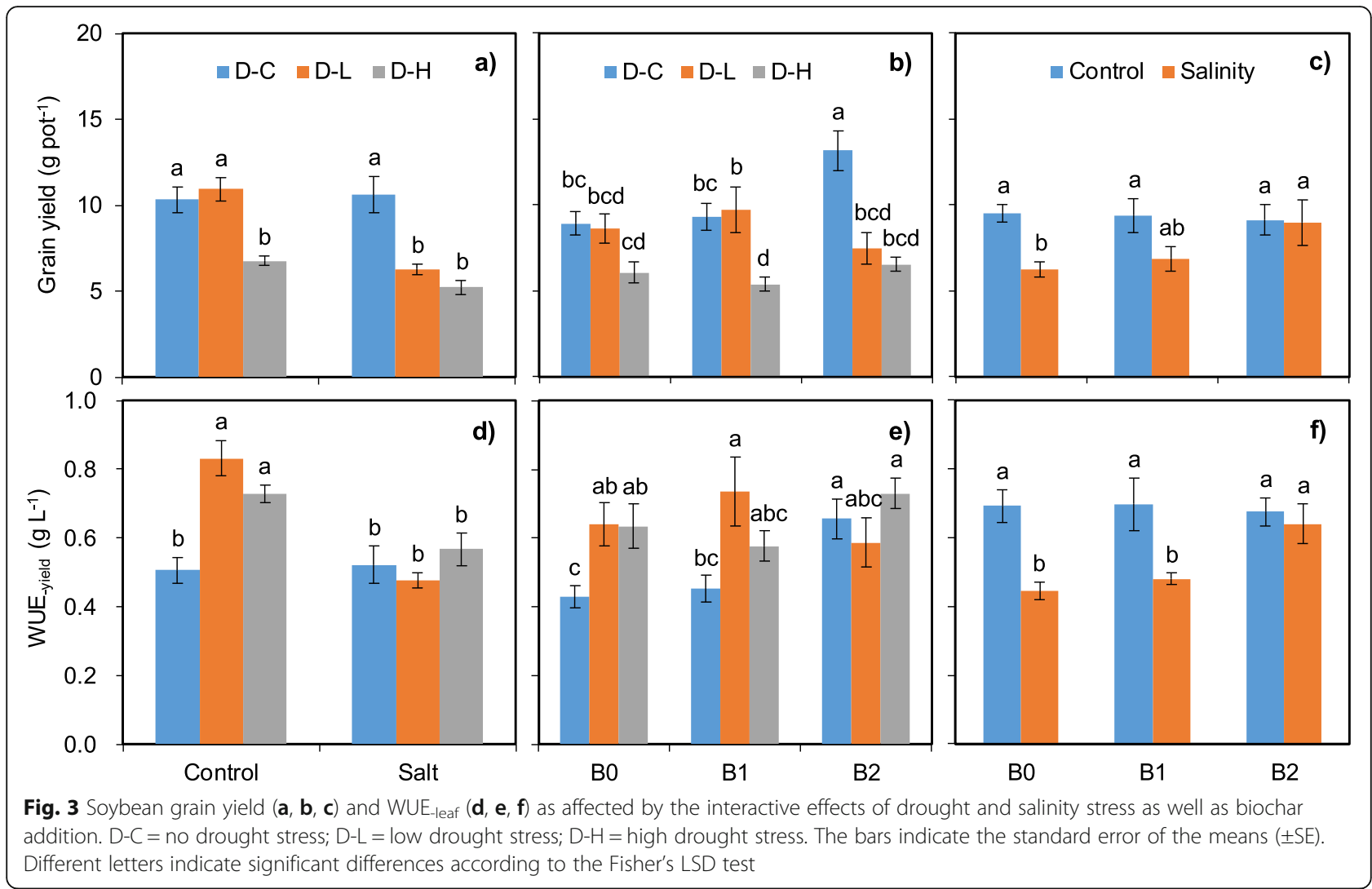

Leaf photosynthetic efficiency plays an important role in regulating crop yield $[15,35,39]$. The present study showed that leaf photosynthetic rate was inhibited by drought and salinity stress, which could cause reduction of soybean yield $[15,16]$. The decrease of photosynthetic rate due to drought stress has been also reported in legume crops $[15,40]$, and has been ascribed to stomatal closure under drought stress [14, 15, 59]. As reported by Hussain et al. [15], stomatal closure mediated restricted $\mathrm{CO}_{2}$ diffusion in the leaves is more dominating compared to $\mathrm{CO}_{2}$ assimilation, thus could decline leaf photosynthetic rate and crop productivity. In accordance with previous studies, the reduction of photosynthetic rate in the present study can be ascribed to two distinct mechanisms: 1) through decreased $\mathrm{CO}_{2}$ diffusion within the leaf due to stomatal closure (decreased by 56.7 and 80.3\% under low and high drought stress, respectively). 2) through decreased the enzyme at the acceptor site of ribulose-1, 5-bisphosphate carboxylase/oxygenase or inhibit photosynthetic enzymes due to lower intercellular $\mathrm{CO}_{2}$ concentration $[16,40,41]$. Similarly, the intercellular $\mathrm{CO}_{2}$ concentration is also considered as a key factor assessing the effects of salinity on photosynthetic efficiency $[21,42]$. Soil salinity stress could lead to enhance leaf cellular $\mathrm{Na}^{+}$and $\mathrm{Cl}^{-}$concentrations, then depress cell expansion and photosynthetic activity and thereafter accelerate leaf senescence, thus resulting in crop yield reduction [21, 43]. Otherwise, salinity tolerant plant showed a better intercellular $\mathrm{CO}_{2}$ concentration in the leaf for the photosynthetic rate [23].

Root, the first organ to adapt and respond sensitively to abiotic stressors in soil (e.g., drought and salinity), plays an important role in regulating plant growth [4446]. To our knowledge, however, few work has been done on root and nodule growth of soybean responding to the interaction of drought and salinity stress. Root architecture, particularly those that can entrench deeper with longer root length in the soil, plays an important role in maximizing the ability of plants to gain soil water and nutrients for plant growth [44, 47]. Accompanied with strategies that reduce water loss, such as stomatal closure and leaf transpiration rate weaken, the augment in root length could increase soil water and nutrients obtain that is necessary to support biomass production and grain yield of soybean [44]. As shown in this study, root length was longer under drought condition than the control for acquiring more water and nutrition easier. On the contrary, root nodules were decreased sharply accompanied with soybean grain yield under drought and salinity stress. These findings suggest that in addition to root performance, the ability to develop and maintain root nodules may also be a crucial trait regulating the grain productivity of soybean. Although salinity addition showed no effect on root length and nodule 
weight, the interaction of drought and salinity suggests that we should consider the comprehensive influence of salinity on soybean productivity under drought stress, because root growth and nodule performance are crucial parameters associated with soybean productivity.

Biochar application to low fertility or pollutant soils as a promising approach to improve soil quality and thus enhance crop yield has been well reported in previous studies [30-32, 48]. Actually, biochar application in field could enhance crop yield mainly ascribed to the regulation in soil $\mathrm{pH}$ [49], increase soil C storage [50], and retain soil water and nutrient [51]. In the present study, biochar addition significantly enhanced shoot biomass, root biomass and grain yield. These phenomenon could also be partially ascribed to the alternation in leaf physiological variables (e.g. photosynthesis). For example, biochar addition significantly enhanced soybean leaf photosynthetic rate and stomatal conductance (Table 1), this could give rise to a positive effect on leaf and soil available $\mathrm{N}$ content and thus increase soybean grain yield [52].

In rain-fed and semiarid regions, WUE has been regarded as an important trait indicating crop productivity, which links water and nutrient cycling in agroecosystems [39]. However, few studies have focused on how the WUE responded to drought and salinity stress at different scales, such as at leaf and yield levels. Drought and salinity stress showed the same effect on enhancing WUE at leaf scale in the present study (Table 1). The positive effect of drought and salinity on $\mathrm{WUE}_{\text {-leaf }}$ is largely due to leaf stomatal closure and transpiration rate reduction under the external stress [53, 54], thus leads to water evaporation less and water use more efficiency for the leaf. However, at the yield scale, WUE was enhanced significantly by drought stress but decreased significantly by salinity stress. The inversed results were probability caused by root growth responded differently to drought and salinity stress, which is sensitively to obtain water from soil [55]. Furthermore, the interactive of drought and salinity stress significantly affected WUE at both leaf and yield levels, which means we should consider the comprehensive influence of drought and salinity on WUE in the future for sustainable agriculture.

\section{Conclusions}

This study shows that both drought and salinity stress delayed soybean flowering time and depressed leaf gas exchange parameters (e.g., photosynthetic rate, stomatal conductance, intercellular $\mathrm{CO}_{2}$ concentration and transpiration rate) with negative effect on grain yield. Biochar addition significantly increased plant biomass and grain yield. Drought stress showed an increase of $\mathrm{WUE}_{\text {-leaf }}$ and WUE $_{\text {-yield }}$ while salinity stress showed a reduction of
WUE-yield. Effective use of water implies maximal soil moisture capture for transpiration, which may be use to replace WUE in the future with drought stress. The results of this study indicate that drought and salinity stress effect on soybean productivity and WUE are highly conspicuous, while biochar amendment could alleviate the negative effects. We should take into account the employment of biochar and interactive effects of abiotic stressors for sustainable agriculture in the future.

\section{Methods}

\section{Soil sampling and biochar description}

Soil samples $(0-20 \mathrm{~cm}$ depth cores) were collected from a sandy-loam vertisol (USDA soil classification system) managed with maize (Zea mays L.) and wheat (Triticum aestivum L.) crop rotation at the Research and Education Farm of Henan University, China ( $34^{\circ} 49^{\prime} \mathrm{N}, 114^{\circ}$ $17^{\prime} \mathrm{E}, 73 \mathrm{~m}$ a.s.l). The mean annual temperature is $14.5^{\circ} \mathrm{C}$, with monthly mean temperature ranging from $0.16^{\circ} \mathrm{C}$ in January to $27.1^{\circ} \mathrm{C}$ in July (China Meteorological Data Sharing Service System). Mean annual precipitation is $627 \mathrm{~mm}$, with $87.8 \%$ distributing from April to October. The soil parent material is mainly formed from Yellow River sediment, consisting of $65.6 \%$ sand, $14.1 \%$ silt and $20.3 \%$ clay with an initial $\mathrm{pH}$ of $8.6(1: 2.5$, water/soil, w/w) and an average bulk density of $1.35 \mathrm{~g}$ $\mathrm{cm}^{-3}$. Total $\mathrm{N}$ and organic $\mathrm{C}$ contents were $0.47 \mathrm{~g} \mathrm{~kg}^{-1}$ and $11.04 \mathrm{~g} \mathrm{~kg}^{-1}$, respectively. The electrical conductivity of saturated soil-paste extract (ECe) is $10.6 \mathrm{dS} \mathrm{m}^{-1}$.

Biochar used in this study was produced from wheat straw under pyrolysis temperature of $550^{\circ} \mathrm{C}$ at the Sanli New Energy Company in Henan, China. The main properties of biochar were reported in our previous study [56]: total organic C $467.2 \mathrm{~g} \mathrm{~kg}^{-1}$, total $\mathrm{N} 6 \mathrm{~g} \mathrm{~kg}^{-1}, \mathrm{pH}$ 10.9 and ash content $20.8 \%$.

\section{Experimental design}

A $3 \times 2 \times 3$ factorial design pot experiment was conducted with the following main factors: 1) drought stress (main factor): soil moisture was kept at $75-80 \%$ WHC as control (D-C), 40-45\% WHC as low drought stress (D-L), 20-25\% WHC as high drought stress (D-H); 2) salinity stress (secondary factor): background soil as control and salinity addition at $1 \mathrm{~g} \mathrm{~kg}^{-1}$ dry soil as the salinity stress treatment; 3 ) biochar addition (thirdly factor): biochar applied at 0,5 , and $10 \mathrm{~g} \mathrm{~kg}^{-1}$ soil as control (B0), low (B1) and high (B2) biochar addition rate, respectively. In total, there were eighteen treatment combinations replicated four times for a total of 72 pots. In each plastic pot (with a circle radius of $20 \mathrm{~cm}$ and height of $25 \mathrm{~cm}$ ), $5.6 \mathrm{~kg}$ soil (air dried weight basis) was added and soil surface was subsequently levelled before soybean sowing. The pot experiment was carried out in a rain shelter covered with glass. 
Drought stress was controlled based on soil moisture with an electronic balance after thinning seedlings. Every 1 or 2 days, experiment pots were weighted and distilled water was used to replenish water loss if it was necessary. Salinity stress was adjusted by mixing $\mathrm{NaCl}$ into soil. $\mathrm{Na}^{+}$content was $0.03 \mathrm{~g} \mathrm{~kg}^{-1}$ in the background soil, but we refer to the background soil as the control treatment as none $\mathrm{Na}^{+} . \mathrm{NaCl}$ and biochar was mixed thoroughly with soil prior to experiment start according to pre-determined amount.

The pot experiment was lasted 107 days, it began on June 30 and ended on October 15 in 2018. The soybean variety (Named Zhonghuang 35, produced by Anhui Mindeli Seed Co. LTD) used in this experiment was one of the most widely planted variety in this region. Six well-selected soybean seeds were sowing in each pot. Thinning seedlings occurred after 20 days of sowing when the soybean plants have 3 or 4 cotyledons and two soybean plants were remained in each pot. Drought stress started after thinning seedlings.

\section{Leaf gas exchange measurements}

The third leaf from the top plant was used to determine the leaf photosynthetic physiology at soybean flowering stage, including photosynthetic rate $\left(P_{-\max }\right)$, stomatal conductance (Cond), intercellular $\mathrm{CO}_{2}$ concentration (Ci) and transpiration rate $(\mathrm{Tr})$. The leaf photosynthetic physiology parameters was measured (two times on $\mathrm{Au}$ gust 4, 2018 and August 11, 2018) by using an open gasexchange system (Li-6400; Li-Cor Inc.) in the cloudless day between 08:00 to 11:00 (local time). During the measurement, leaves were illuminated at $1500 \mu \mathrm{mol} \mathrm{m}^{-2}$ $\mathrm{s}^{-1}$ using the LED light system. We did not intervene environmental changes, including leaf temperature, water vapor or $\mathrm{CO}_{2}$ concentrations. Leaf level WUE $\left(\mathrm{WUE}_{\text {-leaf }}\right.$ ) was calculated as: $\mathrm{WUE}_{\text {-leaf }}=P_{\text {-max }} / \operatorname{Tr}$ [57].

\section{Grain yield, biomass and WUE at yield level (WUE-yield) measurement}

Grain yield from each pot was collected in mesh bags and air-dried for weighing. At the same time, soybean shoot samples were taken from each pot and oven-dried at $70{ }^{\circ} \mathrm{C}$ to constant weight for calculating the shoot biomass. For the soybean root, we have washed the root cleanly and measured root length.

WUE at the yield level was calculated by dividing the soybean grain yield by water usage [58]:

$$
\mathrm{WUE}_{\text {-yield }}\left(\mathrm{g} \mathrm{L}^{-1}\right)=\text { grain yield/water usage }
$$

\section{Data analysis and statistics}

Leaf gas exchange parameters, soybean grain yield, biomass, root length and WUE were analyzed with three- way ANOVA and significant differences were checked through Fisher LSD test. All the parameters as affected by the interactive of drought stress, salinity stress and biochar addition were addressed in the figures. Statistical analysis of data was performed using SPSS version 21.0 (SPSS Inc.), and statistical significance was determined at the 0.05 probability level. The data are presented as means $\pm \mathrm{SE}(n=4)$.

\section{Acknowledgements}

Not applicable.

\section{Authors' contributions}

$\mathrm{YZ}$ and $\mathrm{CZ}$ conceived and designed the experiment. JD and HW handled the experiment and measured physiological indicators. YZ, JD and LS analyzed the data and wrote the paper. All authors read and approved the final manuscript.

\section{Funding}

This study was supported by the National Natural Science Foundation of China (41701283, U1804101), China Postdoctoral Science Foundation (2019 T120621, 2018 M632760), Kaifeng Science and Technology Planning Project (1902007).

\section{Availability of data and materials}

The datasets used and/or analysed during the current study are available from the corresponding author on reasonable request.

Ethics approval and consent to participate

Not applicable.

\section{Consent for publication}

Not applicable.

\section{Competing interests}

The authors declare that they have no competing interests.

\section{Author details}

${ }^{1}$ School of Life Sciences, Henan University, Kaifeng 475004, Henan, China. ${ }^{2}$ College of Resource and Environment, Anhui Science and Technology University, No. 9 Donghua Road, Chuzhou 233100, China.

Received: 18 December 2019 Accepted: 15 June 2020

Published online: 22 June 2020

References

1. Lobell D, Roberts M, Schlenker W, Braun N, Little B, Rejesus R, Hammer G. Greater sensitivity to drought accompanies maize yield increase in the U.S. Midwest. Nature. 2014;344:516-9.

2. Parvin S, Uddin S, Fitzgerald G, Tausz-Posch S, Armstrong R, Tausz M. Free air $\mathrm{CO}_{2}$ enrichment (FACE) improves water use efficiency and moderates drought effect on $\mathrm{N}_{2}$ fixation of Pisum sativum L. Plant Soil. 2019;436(1-2): 587-606.

3. IPCC. Climate Change 2013: The physical science basis. Contribution of working group I to the fifth assessment report of the intergovernmental panel on climate change. Cambridge University Press, Cambridge.

4. Z Zhang Q, Kong D, Singh V, Shi P. Response of vegetation to different timescales drought across China: spatiotemporal patterns, causes and implications. Glob Planet Chang. 2017;152:1-11.

5. Wang Z, Zhong R, Lai C, Zeng Z, Lian Y, Bai X. Climate change enhances the severity and variability of drought in the Pearl River Basin in South China in the 21st century. Agr Forest Meterol. 2018;249:149-62.

6. Harrison M, Tardieu F, Dong Z, Messina C, Hammer G. Characterizing drought stress and trait influencing on maize yield under current and future conditions. Glob Chang Biol. 2014;20(3):867-78.

7. Lobell D, Hammer G, Chenu K, Zheng B. Mclean Gm chapman S. the shifting influence of drought and heat stress for crops in Northeast Australia. Glob Chang Biol. 2015;21(11):4115-27. 
8. Zipper S, Qiu J, Kucharik C. Drought effects on US maize and soybean production: spatiotemporal patterns and historical changes. Environ Res Lett. 2016;11(9):094021.

9. Wang P, Yang C, Chen H, Song C, Zhang X, Wang D. Transcriptomic basis for drought resistance in Brassica napus L. Sci Rep. 2017;7:40532.

10. Mega R, Abe F, Kim J, Tsuboi Y, Tanaka K, Kobayashi H, Sakata Y, Hanada K, Tsujimoto H, Kikuchi J, Cutler S, Okamoto M. Tuning water-use efficiency and drought tolerance in wheat using abscisic acid receptors. Nat Plants. 2019:5:153-9.

11. He J, Du Y, Wang T, Turner N, Yang R, Jin Y, Xi Y, Zhang C, Cui T, Fang X, Li F. Conserved water use improves the yield performance of soybean (Glycine max (L.) Merr.) under drought. Agr Water Manage. 2017;179:236-45.

12. Edwards C, Ewers B, McClung C, Lou P, Weinig C. Quantitative variation in water-use efficiency across water regimes and its relationship with circadian vegetative, reproductive, and leaf gas-exchange traits. Mol Plant. 2012:5(3): 653-68.

13. Jaleel C, Manivannan $P$, Wahid A, Faroog M, Somasundaram R, Panneerselvam R. Drought stress in plants: a review on morphological characteristics and pigments composition. Int J Agric Biol. 2009;11(1):100-5.

14. Mathobo R, Marais D, Steyn J. The effect of drought stress on yield, leaf gaseous exchange and chlorophyll fluorescence of dry beans (Phaseolus vulgaris L.). Agr Water Manage. 2017;180:118-25.

15. Hussain M, Farooq S, Hasan W, Ul-Allah S, Tanveer M, Farooq M, Nawaz A. Drought stress in sunflower: physiological effects and its management through breeding and agronomic alternatives. Agr Water Manage. 2018;201: 152-66.

16. Faroog M, Gogoi N, Barthakur S, Baroowa B, Bharadwaj N, Alghamdi S, Siddique $\mathrm{H}$. Drought stress in grain legumes during reproduction and grain filling. J Agron Crop Sci. 2017;203(2):81-102.

17. Fang $X$, Turner N, Yan G, Li F, Siddique K. Flower numbers, pod production, pollen viability, and pistil function are reduced and flower and pod abortion increased in chickpea (Cicer arietinum L.) under terminal drought. J Exp Bot. 2010;61(2):335-45.

18. Bengough A, McKenzie B, Hallett $P$, Valentine T. Root elongation, water stress, and mechanical impedance: a review of limiting stresses and beneficial root tip traits. J Exp Bot. 2011;62(1):59-68.

19. Prince S, Murphy M, Mutava R, Durnell L, Valliyodan B, Shannon J, Nguyen $H$. Root xylem plasticity to improve water use and yield in water-stressed soybean. J Exp Bot. 2017;68(8):2027-36.

20. Hammer G, Dong Z, McLean G, Doherty A, Messina C, Schussler J, Zinselmeier C, Paszkiewicz S, Cooper M. Can changes in canopy and/or root system architecture explain historical maize yield trends in the US corn belt? Crop Sci. 2009;49(1):299-312.

21. Munns R, Gilliham M. Salinity tolerance of crops - what is the cost? New Phytol. 2015;208(3):668-73.

22. Li W, Zhao F, Fang W, Xie D, Hou J, Yang X, Zhao Y, Tang Z, Nie L, LV S. Identification of early salt stress responsive proteins in seedling roots of upland cotton (Gossypium hirsutum L.) employing iTRAQ-based proteomic technique. Front Plant Sci. 2015;6:732.

23. Negrão S, Schmöckel M, Tester M. Evaluating physiological responses of plants to salinity stress. Annal Botany. 2017;119(1):1-11.

24. Amini S, Ghadiri H, Chen C, Marschner P. Salt-affected soils, reclamation, carbon dynamics, and biochar: a review. J Soils Sediments. 2016;16(3):939-53.

25. Parihar $P$, Singh $S$, Singh $R$, Singh V, Prasad $S$. Effects of salinity stress on plants and its tolerance strategies: a review. Environ Sci Pollut R. 2015;22(6):4056-75.

26. Stavridou $E$, Hastings A, Webster R, Robson P. The impact of soil salinity on the yield, composition and physiology of the bioenergy grass Miscanthus $\times$ giganteus. GCB Bioenergy. 2017;9(1):92-104.

27. Munns R. Comparative physiology of salt and water stress. Plant Cell Environ. 2002;25(2):239-50.

28. Han S, Wang C, Wang W, Jiang L. Mitogen-activated protein kinase 6 controls root growth in Arabidopsis by modulating $\mathrm{Ca}^{2+}$-based $\mathrm{Na}^{+}$flux in root cell under salt stress. J Plant Physiol. 2014;171(5):26-34.

29. Schilling R, Marschner P, Shavrukov Y, Berger B, Tester M, Roy S, Plett D. Expression of the Arabidopsis vacuolar $\mathrm{H}^{+}$-pyrophosphatase gene (AVP1) improves the shoot biomass of transgenic barley and increases grain yield in a saline field. Plant Biotechnol J. 2014;12(3):378-86.

30. Lehmann J. A handful of carbon. Nature. 2007:447:143-4.

31. Jeffery $S$, Verheijen $F$, van der Velde $M$, Bastos A. A quantitative review of the effects of biochar application to soils on crop productivity using metaanalysis. Agric Ecosyst Environ. 2011;144(1):175-87.
32. Hussain M, Farooq M, Nawaz A, Al-Sadi A, Solaiman Z, Alghamdi S, Ammara U, Ok Y, Siddique K. Biochar for crop production: potential benefits and risks. J Soils Sediments. 2017;17:685-716.

33. Raboin L, Razafimahafaly A, Rabenjarisoa M, Rabary B, Dusserre J, Becquer T. Improving the fertility of tropical acid soils: liming versus biochar application? A long-term comparison in the highlands of Madagascar. Field Crop Res. 2016;199:99-108.

34. Cao D, Li Y, Liu B, Kong F, Tran L. Adaptive mechanisms of soybean grown on salt-affected soils. Land Degrad Dev. 2018;29(4):1054-64.

35. Mutava R, Prince S, Syed N, Song L, Valliyodan B, Chen W, Nguyen H. Understanding abiotic stress tolerance mechanisms in soybean: a comparative evaluation of soybean response to drought and flooding stress. Plant Physiol Bioch. 2015;86:109-20.

36. Kunert K, Vorster B, Fenta B, Kibido T, Dionisio G, Foyer C. Drought stress responses in soybean roots and nodules. Front Plant Sci. 2016;7:1015.

37. Baroowa B, Gogoi N. Biochemical changes in black gram and green gram genotypes after imposition of drought stress. J Food Legume. 2014;27:350-3.

38. Fleury D, Jefferies $S$, Kuchel $H$, Langridge P. Genetic and genomic tools to improve drought tolerance in wheat. J Exp Bot. 2010;61(12):3211-22.

39. Li N, Zhou C, Sun $X$, Jing J, Tian $X$, Wang L. Effects of ridge tillage and mulching on water availability, grain yield, and water use efficiency in rainfed winter wheat under different rainfall and nitrogen conditions. Soil Till Res. 2018;179:86-95.

40. Girma F, Haile D. Effects of supplemental irrigation on physiological parameters and yield of faba bean (Vicia faba L.) varieties in the highlands of bale, Ethiopia. J Agron. 2014;13(1):29-34.

41. Zlatev Z, Lidon F. An overview on drought induced changes in plant growth, water relations and photosynthesis. Emir J Food Agr. 2012; 24(1):57-72.

42. Stepien $\mathrm{P}$, Johnson G. Contrasting responses of photosynthesis to salt stress in the glycophyte Arabidopsis and the halophyte Thellungiella: role of the plastid terminal oxidase as an alternative electron sink. Plant Physiol. 2009; 149:1154-65.

43. Michelbart M, Hasegawa P, Bailey-Serres B. Genetic mechanisms of abiotic stress tolerance that translate to crop yield stability. Nat Rev Genet. 2015;16: 237-51.

44. Fenta B, Beebe S, Kunert K, Burridge J, Barlow K, Lynch J, Foyer C. Field phenotyping of soybean roots for drought stress tolerance. Agronomy. 2014:4(3):418-35.

45. Rolli E, Marasco R, Vigani G, Ettoumi B, Mapelli F, Deangelis M, Gandolfi C, Casati E, Previtali F, Gerbino R, Pierotti F, Borin S, Sorlini C, Zocchi G, Daffonchio D. Improved plant resistance to drought is promoted by the root-associated microbiome as a water stress-dependent trait. Environ Microbiol. 2015;17(2):316-31.

46. West $G$, Inzé D, Beemster G. Cell cycle modulation in the response of the primary root of Arabidopsis to salt stress. Plant Physiol. 2004;135:1050-8.

47. Robbins N, Dinneny J. Growth is required for perception of water availability to pattern root braches in plants. P Natl Acad Sci USA. 2018;115(4):E822-31.

48. Kamau S, Karanja N, Ayuke F, Lehmann J. Short-term influence of biochar and fertilizer-biochar blends on soil nutrients, fauna and maize growth. Biol Fert Soils. 2019;55(7):661-73.

49. Sun $H$, Lu H, Chu L, Shao H, Shi WM. Biochar applied with appropriate rates can reduce $\mathrm{N}$ leaching, keep $\mathrm{N}$ retention and not increase $\mathrm{NH}_{3}$ volatilization in a coastal saline soil. Sci Total Environ. 2017:575:820-5.

50. Obia A, Mulder J, Martinsen V, Cornelissen G, Børresen T. In situ effects of biochar on aggregation, water retention and porosity in light-textured tropical soils. Soil Till Res. 2016;155:35-44.

51. Fischer B, Manzoni S, Morillas L, Garcia M, Johnson M, Lyon S. Improving agricultural water use efficiency with biochar-a synthesis of biochar effects on water storage and fluxes across scales. Sci Total Environ. 2019;657:853-62.

52. Xu C, Hosseini-Bai S, Hao Y, Rachaputi R, Wang H, Xu Z, Wallace H. Effect of biochar amendment on yield and photosynthesis of peanut on two types of soils. Environ Sci Pollut Res. 2015;22(8):6112-25.

53. Medrano H, Tomás M, Martorell S, Flexas J, Hernández E, Rosselló J, Pou A Escalona J, Bota J. From leaf to whole-plant water use efficiency (WUE) in complex canopies: limitations of leaf WUE as a selection target. Crop J. 2015;3(3):220-8.

54. Wang C, Wu S, Tankari M, Zhang X, Li L, Gong D, Hao W, Zhang Y, Mei X, Wang Y, Liu F, Wang Y. Stomatal aperture rather than nitrogen nutrition 
determined water use efficiency of tomato plants under nitrogen fertigation. Agr Water Manage. 2018;209:94-101.

55. Uddin S, Löw M, Parvin S, Fitzgerald G, Bahrami H, Tausz-Posch S, Armstrong R, O'Leary G, Tausz M. Water use and growth responses of dryland wheat grown under elevated $\left[\mathrm{CO}_{2}\right]$ are associated with root length in deeper, but not upper soil layer. Field Crop Res. 2018;224:170-81.

56. Zhang Y, Wang H, Maucieri C, Liu S, Zou J. Annual nitric and nitrous oxide emissions response to biochar amendment from an intensive greenhouse vegetable system in Southeast China. Sci Hortic. 2019;246:879-86.

57. Niu S, Xing X, Zhang Z, Xia J, Zhou X, Song B, Li L, Wan S. Water-use efficiency in response to climate change: from leaf to ecosystem in a temperate steppe. Glob Chang Biol. 2011;17:1073-82.

58. Zhou Q, Ju C, Wang Z, Zhang H, Liu L, Yang J, Zhang J. Grain yield and water use efficiency of super rice under soil water deficit and alternate wetting and drying irrigation. J Integr Agr. 2017;16(5):1028-43.

59. Chaves M, Flexas J, Pinheiro C. Photosynthesis under drought and salt stress: regulation mechanisms from whole plant to cell. Anual Botany. 2009; 103(4):551-60

\section{Publisher's Note}

Springer Nature remains neutral with regard to jurisdictional claims in published maps and institutional affiliations.

Ready to submit your research? Choose BMC and benefit from:

- fast, convenient online submission

- thorough peer review by experienced researchers in your field

- rapid publication on acceptance

- support for research data, including large and complex data types

- gold Open Access which fosters wider collaboration and increased citations

- maximum visibility for your research: over $100 \mathrm{M}$ website views per year

At BMC, research is always in progress.

Learn more biomedcentral.com/submissions 